\title{
Distributional patterns and diets of four species of sea urchins in giant kelp forest (Macrocystis pyrifera) of Puerto Toro, Navarino Island, Chile
}

\author{
J. A. Vásquez, J. C. Castilla and B. Santelices \\ Departamento de Biología Ambiental y de Poblaciones, Facultad de Ciencias Biológicas, Pontificia Universidad Católica \\ de Chile, Casilla 114-D, Santiago, Chile
}

\begin{abstract}
The distribution pattern of microhabitat and diet was studied in 4 species of sea urchins (Loxechinus albus, Pseudechinus magellanicus, Arbacia dufresnei, Austrocidaris canaliculata) in a forest of Macrocystis pyrifera in southern Chile. We conclude that: (1) There is no overlap in space utilization (microhabitat) except for the species pair P. magellanicus - A. canaliculata. (2) All 4 species of sea urchins feed on $M$. pyrifera in different percentages; this results in a high diet overlap in at least 3 of them; however, this resource does not appear to be limiting. (3) Neither competition among adults nor predation on adults appears to be a key factor in regulating the present population densities of the four species of sea urchins in the habitat studied. Our results further indicate that differences in intensity of water movement, correlated with bathymetric distribution, regulate population density, size of test and biomass in these four species.
\end{abstract}

\section{INTRODUCTION}

Sea urchins are among the major grazers structuring communities of kelps in shallow waters of the Northern Hemisphere (Leighton et al., 1965; Jones and Kain, 1967; North and Pearse, 1970; Lawrence, 1975; Foreman, 1977; Mattison et al., 1977; Vadas, 1977; Druehl, 1978; Pearse and Hines, 1979; Vance and Schmitt, 1979). In some cases grazing by sea urchins limits the bathymetric distribution of kelps (Jones and Kain, 1967; Foreman, 1977; Druehl, 1978), in others, it modifies the patterns of distribution of understory vegetation reducing the local abundance (Vance, 1979; Vance and Schmitt, 1979) or even leads to large-scale 'barren grounds' (Leighton et al,, 1965; North and Pearse, 1970; Breen and Mann 1976a, b; Chapman, 1981). The densities of sea urchins, in turn, are thought to be regulated by predation, especially by sea otters in the North Pacific (Lowry and Pearse, 1973; Estes and Palmisano, 1974; Estes et al., 1978; Duggins, 1980) and lobsters in the northern Atlantic (Breen and Mann, 1976a). Removal of these predators has resulted in a substantial increase in the densities of grazers which, in turn, has changed the distribution of the kelp plants (reviewed by Lawrence, 1975).

In the coastal kelp forest of Macrocystis pyrifera at
Puerto Toro, Navarino Island, in the Beagle Channel there are 4 species of sea urchins: Loxechinus albus (Molina), Arbacia dufresnei (Blainville), Pseudechinus magellanicus (Philippi), Austrocidaris canaliculata (Agassiz). Castilla and Moreno (1982) did not identify any predator that might be controlling the population densities of these 4 species. Regulation of the densities of these species therefore may result from competitive interactions. In the absence of enough time and logistic facilities to evaluate experimentally competitive interactions we measured the pattern of distribution of diets and microhabitat of all four species. These measurements provided a means of evaluating the degree of overlap and the possibilities of interspecific competition for a given resource among the species if this were limiting. In this study we report such measurements and suggest coexistence of the 4 sea urchin species with clear separation of the microhabitat used and the diet consumed by the 4 species.

\section{MATERIAL AND METHODS}

The 4 species of sea urchins were sampled by SCUBA diving (Sep and Nov, 1979; Jan, Apr and Jul, 1980 ) in the coastal beds of Macrocystis pyrifera 


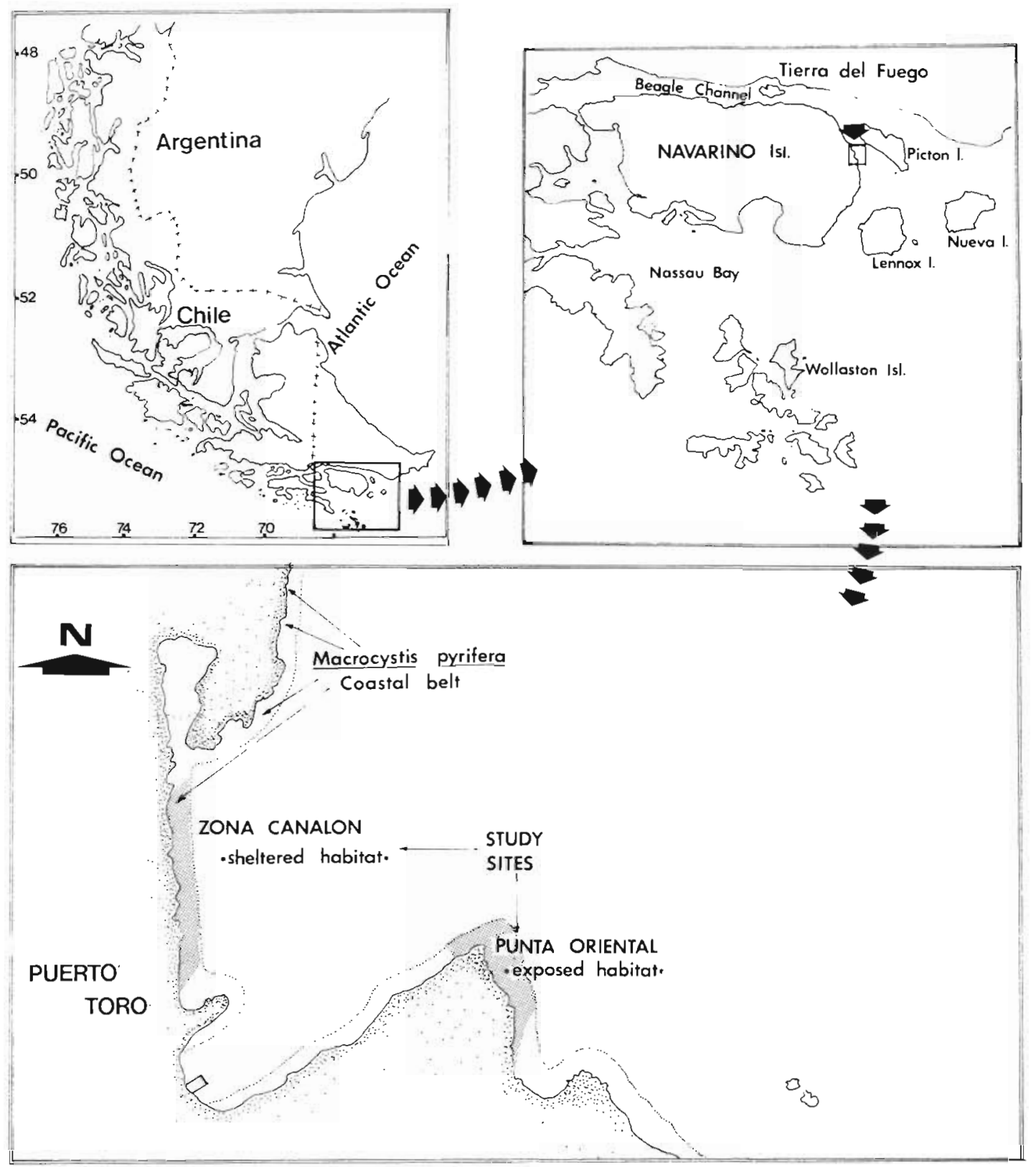

Fig. 1. Map of study area. Coastal belt of Macrocystis pyrifera near Puerto Toro, Navarino Island, southern Chile

at Puerto Toro, Navarino Island $\left(55^{\circ} 4^{\prime} 24^{\prime \prime} \mathrm{S}\right.$; $67^{\circ} 3^{\prime} 50^{\prime \prime} \mathrm{W}$ ) (Fig. 1). For a more detailed description of the study site and of the forest of $M$. pyrifera see Santelices and Ojeda (1984).

The basic sampling unit was a $2 \mathrm{~m}$ wide, $50 \mathrm{~m}$ long transect, extending from the coastline to the seaward edge of the forest. The transect was regularly divided into $10,5 \mathrm{~m}$ long, $2 \mathrm{~m}$ wide sampling units as shown in Fig. 2. All the sea urchins found in each sampling unit were collected, placed in previously tagged sampling bags and transported to the field station. There they were counted, wet weighed and the diameter of test measured. Observations on the spatial distribution and microhabitat utilization of the 4 species were simultaneously recorded along each transect. The localization of the 4 species of sea urchins was noted in relation to 4 types of microhabitat defined as: on boulders, in holdfasts, under boulders and in crevices. Sampling was performed at two different sites, each with different intensities on water motion. Punta Oriental (Fig. 1) was selected as the exposed locality while Zona Canalón was selected as the sheltered habitat. Water movement in both places was measured by dissolution rates of 6 calcium sulfate blocks of 43 to 


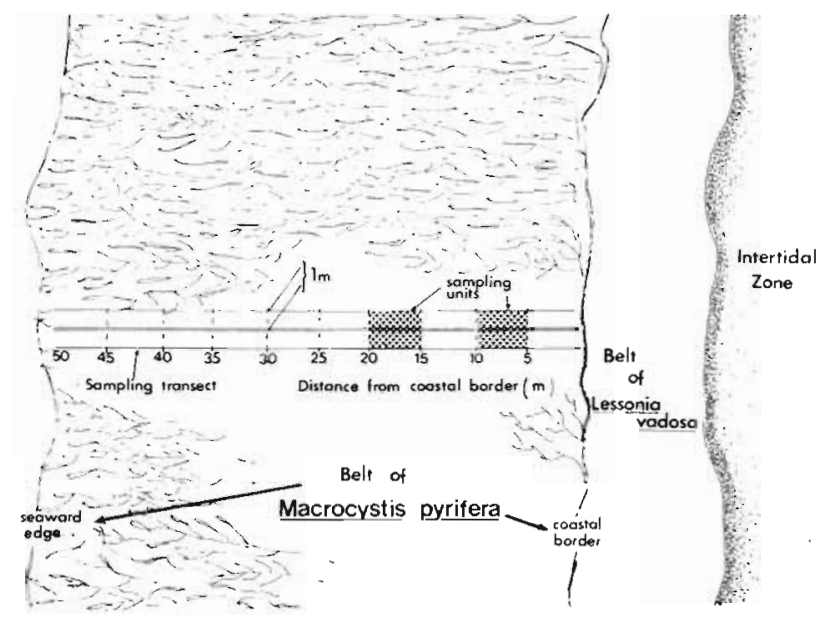

Fig. 2. Diagram of the belt of Macrocystis pyrifera showing sampling transect and sampling units

$44 \mathrm{~g}$ of dry weight mounted on diving leads and placed at each sampling station for $24 \mathrm{~h}$ as recommended by Doty (1971). It is assumed that the loss of weight of the blocks is a function of the dissolution rates produced by water movement (Muus, 1968; Doty, 1971). Because of logistic difficulties, we could not follow the calibration procedures indicated by Doty (1971) to obtain diffusion values. Therefore we calculate our results as the percentage of the original weight lost by the blocks during the $24 \mathrm{~h}$ of exposure in the field.

To study the diet, the gut contents of 55 individuals were analyzed after fixing the urchins in the field with $10 \%$ formaldehyde diluted in sea water. A total of 13 specimens of Loxechinus albus, 14 of Arbacia dufresnei, 17 of Pseudechinus magellanicus and 11 of Austrocidaris canaliculata were collected. At the laboratory, the volumes of gut contents of all collected specimens were standardized to $60 \mathrm{ml}$, adding the same fixative. There subsamples of each sea urchin were analyzed. Each subsample was transferred to a reticulate Petri dish with 30 intersection points. The presence of the items at the intersection points provided an estimate of the relative abundance of the alimentary items in the diet of each of the sea urchin species. To calculate abundance, the total number of points intercepted by any taxa of food items were added for any given species of sea urchin.

\section{RESULTS}

The bathymetric distribution of the 4 species of sea urchins during the sampling months in the 2 forests of Macrocystis pyrifera in Puerto Toro are shown in Fig. 3 and 4. Depth increased at Punta Oriental from 0 to $16 \mathrm{~m}$, with a slope of $32 \%$ and average weight lost by the calcium sulfate blocks of $21.9 \%$ of their original weight after $24 \mathrm{~h}$ of exposure. Zona Canalón had a depth range of 0 to $10 \mathrm{~m}$, with a slope of $20 \%$ and weight loss of calcium sulfate blocks of $16 \%$. Both stations have similar distribution of substratum (Fig. 3 and 4) and somewhat similar densities of $M$. pyrifera individuals ( 1 to 5 plants $5 \mathrm{~m}^{-2}$ ).

Loxechinus albus in Punta Oriental (Fig. 3) was found between 1 and $16 \mathrm{~m}$ deep extending across the whole belt of Macrocystis pyrifera. In Zona Canalón (Fig. 4) it was found between 1 and $8 \mathrm{~m}$ depth, but it was absent from the most seaward border of the forest where the substrate was mainly sand. Pseudechinus magellanicus similarly extended in Punta Oriental along the whole forest while in Zona Canalón it occurred between 1 and $8 \mathrm{~m}$ depth, but reached $5 \mathrm{~m}$ further seaward than L. albus. Austrocidaris canaliculata was restricted in Punta Oriental to depths of 4 to $12 \mathrm{~m}$, while it occurred between 2 and $6 \mathrm{~m}$ depth in Zona Canalón. In both places, therefore, the species was restricted to middle portions of the forest. Arbacia dufresnei was similarly found between 4 and $12 \mathrm{~m}$ depth in Punta Oriental and 2 and $8 \mathrm{~m}$ depth in Zona Canalón. With the exception of $A$. dufresnei, all other species of sea urchins exhibited less extended bathymetric distribution in the sheltered locality.

Loxechinus albus showed significant variations in the size of the test at different depths (Fig. 5). The urchins found between 2 and $4 \mathrm{~m}$ depth were smaller than the specimens collected further beyond in the forest. Arbacia dufresnei showed the opposite tendency, the urchins found in the first part of the forest of Macrocystis pyrifera are bigger than the individuals collected in the deeper part of the forest.

A comparison of the values of density, biomass and size of the test among the populations of the 4 sea urchin species in both sampling sites indicated that Loxechinus albus was the most important species as far as biomass was concerned while Pseudechinus magellanicus had the highest density (Table 1). Both L. albus and $P$. magellanicus have the same range of distribution. Average densities of the 4 species of sea urchins in the 2 sampling transects (Fig. 3 and 4; Table 1) changed from the area with more in the area with less water movement. L. albus had in Punta Oriental densities 6 times higher than in Zona Canalón, while P. magellanicus and Arbacia dufresnei in Punta Oriental were almost twice as abundant as in Zona Canalón. By contrast, Austrocidaris canaliculata show the opposite trend being much less abundant in Punta Oriental than in Zona Canalón. The patterns of change found when examining size of test and biomass distribution are similar to the trends shown by density values (Table 1).

The number of observations and the probability of 
PUNTA ORIENTAL (exposed habitat)
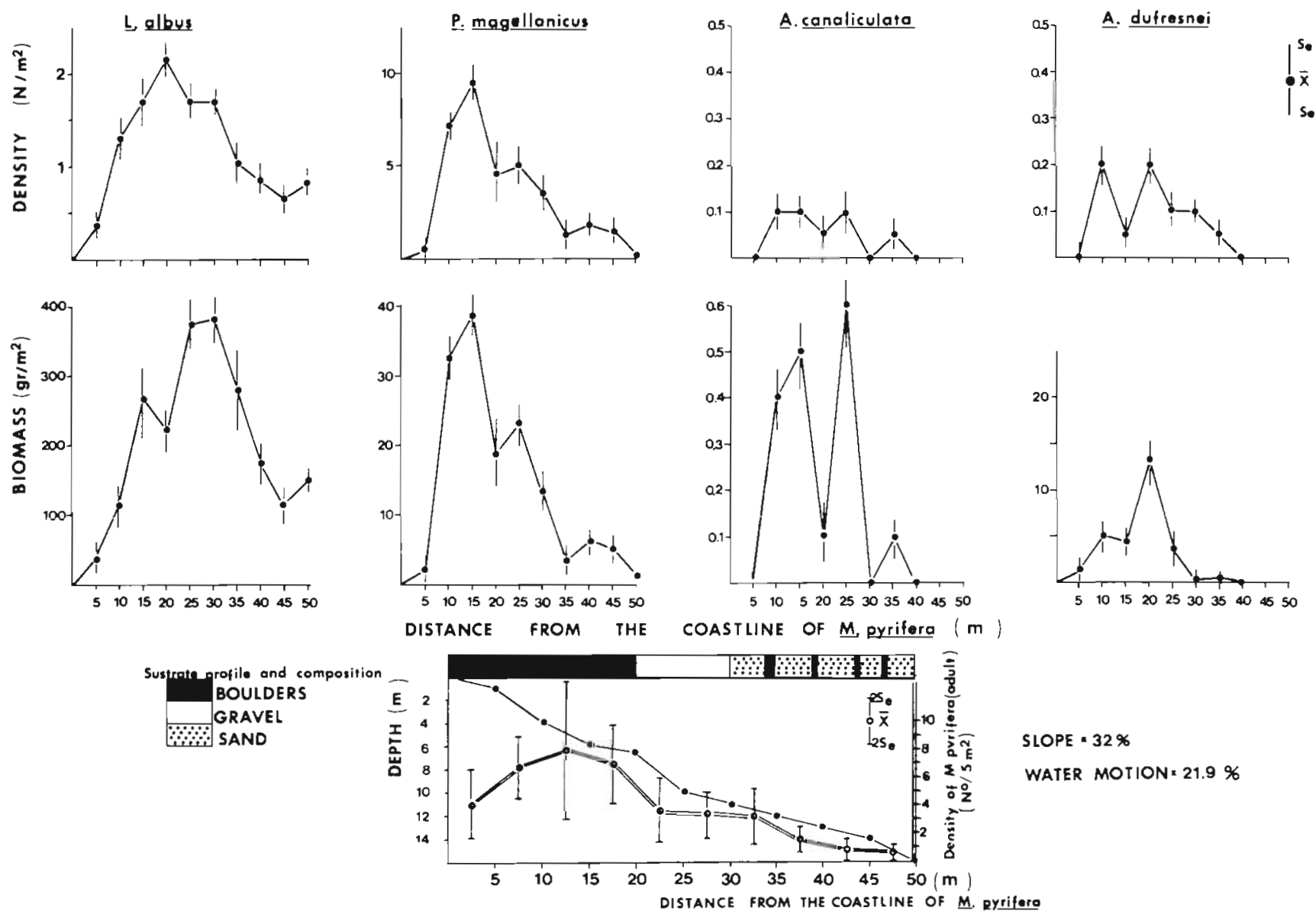

Fig. 3. Density and biomass distribution of the 4 species of sea urchins at the exposed habitat in the forest of Macrocystis pyrifera in Puerto Toro, southern Chile. Units in ordinate different for the various species. Substratum profile (solid circles) and composition and density of adult plants of $M$. pyrifera (open circles) on sampling transect given in lower diagram

Table 1. Size of test, average biomass, average density and range of depth shown by 4 species of sea urchins occurring at 2 study sites in the forest of Macrocystis pyrifera in Puerto Toro, Navarino Island

\begin{tabular}{|c|c|c|c|c|c|c|c|c|}
\hline \multirow[t]{2}{*}{ Species } & \multicolumn{4}{|c|}{ SHELTERED HABITAT (Zona Canalón) } & \multicolumn{4}{|c|}{ EXPOSED HABITAT (Punta Oriental) } \\
\hline & $\begin{array}{l}\text { Size of test } \\
(\mathrm{cm}) \\
\overline{\mathrm{X}} \pm \mathrm{SD} \\
\text { No. of } \\
\text { ind. }\end{array}$ & 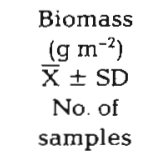 & $\begin{array}{c}\text { Density } \\
\left(\text { No. } \mathrm{m}^{-2}\right) \\
\overline{\mathrm{X}} \pm \mathrm{SD} \\
\text { No. of } \\
\text { samples }\end{array}$ & $\begin{array}{l}\text { Depth } \\
\text { (m) } \\
\text { Range of } \\
\text { collec- } \\
\text { tions }\end{array}$ & $\begin{array}{c}\text { Size of } \\
\text { test }(\mathrm{cm}) \\
\overline{\mathrm{X}} \pm \mathrm{SD} \\
\text { No. of } \\
\text { ind. }\end{array}$ & $\begin{array}{c}\text { Biomass } \\
\left(\mathrm{g} \mathrm{m}^{-2}\right) \\
\overline{\mathrm{X}} \pm \mathrm{SD} \\
\text { No. of } \\
\text { samples }\end{array}$ & $\begin{array}{c}\text { Density } \\
\text { No. } \mathrm{m}^{-2} \\
\mathrm{X} \pm \mathrm{SD} \\
\text { No. of } \\
\text { samples }\end{array}$ & $\begin{array}{c}\text { Depth } \\
\text { (m) } \\
\text { Range of } \\
\text { collec- } \\
\text { tions }\end{array}$ \\
\hline Loxechinus albus & $\begin{array}{c}7.03 \pm 2.04 \\
(100)\end{array}$ & $\begin{array}{c}37.06 \pm 73.9 \\
(20)\end{array}$ & $\begin{array}{c}0.21 \pm 0.41 \\
(20)\end{array}$ & $1-8$ & $\begin{array}{c}7.73 \pm 2.02 \\
(150)\end{array}$ & $\begin{array}{c}210.4 \pm 174.7 \\
(20)\end{array}$ & $\begin{array}{c}1.15 \pm 0.85 \\
(20)\end{array}$ & $1-16$ \\
\hline $\begin{array}{l}\text { Pseudechinus } \\
\text { magellanicus }\end{array}$ & $\begin{array}{c}2.35 \pm 0.37 \\
(100)\end{array}$ & $\begin{array}{l}5.88 \pm 9.5 \\
(20)\end{array}$ & $\begin{array}{c}1.30 \pm 2.1 \\
(20)\end{array}$ & $1-8$ & $\begin{array}{c}2.30 \pm 0.22 \\
(150)\end{array}$ & $\begin{array}{c}14.9 \pm 19.15 \\
(20)\end{array}$ & $\begin{array}{c}3.56 \pm 4.22 \\
(20)\end{array}$ & $1-16$ \\
\hline $\begin{array}{l}\text { Austrocidaris } \\
\text { canaliculata }\end{array}$ & $\begin{array}{c}1.46 \pm 0.28 \\
(100)\end{array}$ & $\begin{array}{c}1.45 \pm 2.88 \\
(20)\end{array}$ & $\begin{array}{c}0.725 \pm 1.35 \\
(20)\end{array}$ & $2-6$ & $\begin{array}{c}1.79 \pm 0.41 \\
(33)\end{array}$ & $\begin{array}{c}0.17 \pm 0.36 \\
(20)\end{array}$ & $\begin{array}{c}0.04 \pm 0.06 \\
(20)\end{array}$ & $4-12$ \\
\hline Arbacia dufresnei & $\begin{array}{c}3.58 \pm 1.31 \\
(27)\end{array}$ & $\begin{array}{c}2.27 \pm 4.1 \\
(20)\end{array}$ & $\begin{array}{c}0.10 \pm 0.15 \\
(20)\end{array}$ & $2-8$ & $\begin{array}{c}3.78 \pm 1.23 \\
(31)\end{array}$ & $\begin{array}{c}2.8 \pm 5.2 \\
(20)\end{array}$ & $\begin{array}{c}0.17 \pm 0.18 \\
(20)\end{array}$ & $4-12$ \\
\hline
\end{tabular}



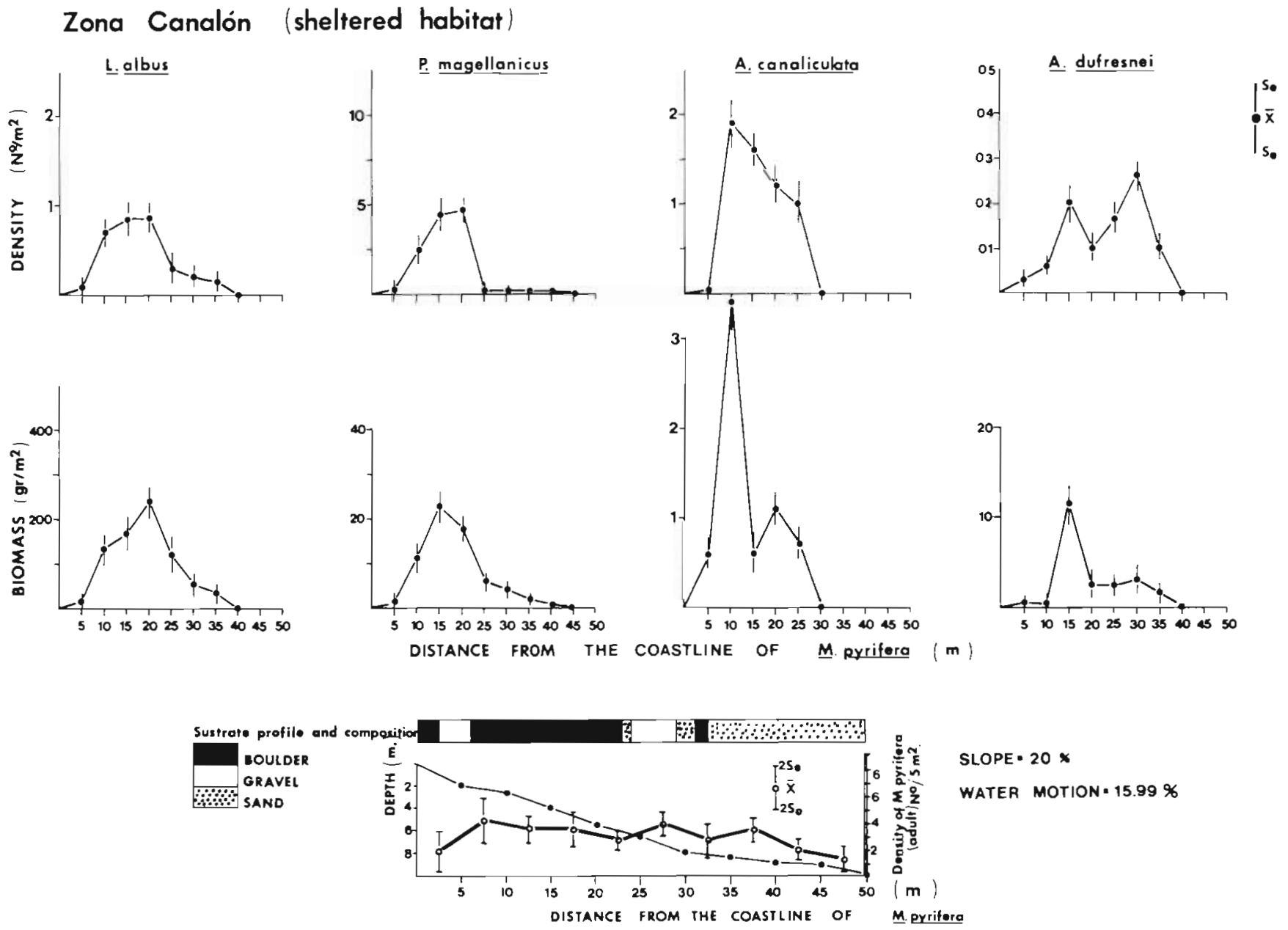

Fig. 4. Density and biomass distribution of the 4 species of sea urchins at the sheltered habitat in the forest of Mactocystis pyrifera in Puerto Toro, southern Chile. Units in ordinate different for the various species. Substratum profile (solid circles) and composition and density of adult plants of $M$. pyrifera (open circles) on sampling transect given in lower diagram

occurrence of each species of sea urchin in each of the four microhabitat categories distinguished are summarized in Table 2. Pseudechinus magellanicus and Austrocidaris canaliculata were found in the $4 \mathrm{mi}$ - crohabitat categories but with different probabilities. $P$. magellanicus occurs more frequently inside the holdfast of Macrocystis pyrifera, while A. canaliculata is more frequently found under boulders. Loxechinus

Table 2. Number of observations and frequency of occurrence of the 4 species of sea urchins in each category of microhabitat distinguished in this study

\begin{tabular}{|c|c|c|c|c|c|c|c|c|}
\hline \multirow[t]{2}{*}{ Microhabitat } & \multicolumn{2}{|c|}{ L. albus } & \multicolumn{2}{|c|}{ P. magellanicus } & \multicolumn{2}{|c|}{ A. canaliculata } & \multicolumn{2}{|c|}{ A. dufresnei } \\
\hline & $\mathrm{N}$ & $\mathrm{P}$ & $N$ & $\mathrm{P}$ & $N$ & $\mathrm{P}$ & $\mathrm{N}$ & $P$ \\
\hline On boulders & 70 & 78.6 & 4 & 4.3 & 4 & 8.7 & 35 & 100 \\
\hline Under boulders & 18 & 20.2 & 40 & 43.01 & 29 & 63.04 & 0 & 0.00 \\
\hline $\begin{array}{l}\text { Inside holdfast } \\
\text { of } M \text {. pyrifera }\end{array}$ & 0 & 0.00 & 44 & 47.3 & 7 & 15.2 & 0 & 0.00 \\
\hline In rock crevasses & 1 & 1.12 & 5 & 5.4 & 6 & 13.04 & 0 & 0.00 \\
\hline Total & 89 & & 93 & & 46 & & 35 & \\
\hline
\end{tabular}

$\mathrm{N}$ : number of observations; P: probability of occurrence of a given species in a given microhabitat

Total number of observations $=263$ 

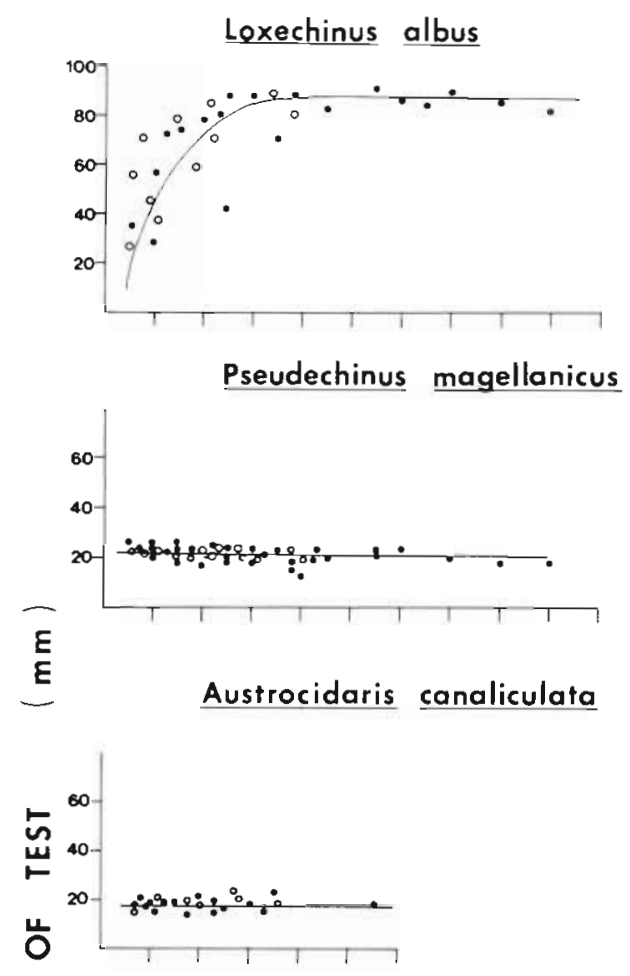

Q

Arbacia dufresnei

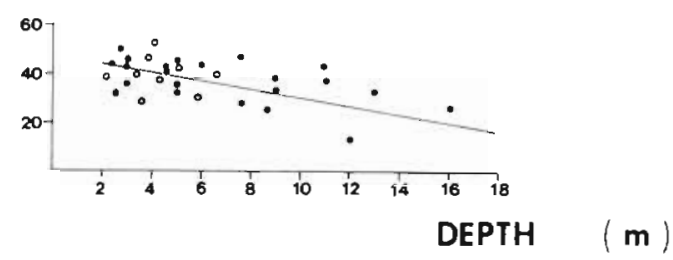

Fig. 5. Changes in test diameter of the 4 species of sea urchins as function of depth. Pooled values gathered in the 2 sampling sites. Open circles: data from Zona Canalóni dark circles: data from Punta Oriental

albus was commonly found on boulders, less frequently found in rock crevasses or under boulders and never found inside the holdfasts of $M$. pyrifera.

The abundance of the different food items found in 3 replicate dishes with gut contents of the 13 individuals of Loxechinus albus, 17 individuals of Pseudechinus magellanicus, 14 of Arbacia dufresnei and 11 individuals of Austrocidaris canaliculata examined are shown in Table 3 . Data indicate that $L$. albus had the most diversified diet of benthic algae, Macrocystis pyrifera being the most frequent item. $P$. magellanicus consumed mainly $M$. pyrifera, whereas $A$. dufresnei and A. canaliculata contained other frondose benthic algae and sessile invertebrates; $A$. dufresnei was particularly notable with over $50 \%$ of the gut content being serpulids and barnacles.
If the gut contents obtained in the 4 sea urchin species are grouped according to their nature, it is possible to distinguish 4 groups of food: (a) Macrocystis pyrifera fronds, which is the commonest item; (b) other frondose algae (mainly Gigartina skottsbergii, Halopteris hordacea, Lessonia spp., Epymenia falklandica); (c) calcareous algae (crustose coralline); and (d) invertebrates (barnacles, serpulids, sponges). These 4 categories together with the 4 microhabitat categories have been used as axes to characterize the utilization of these items by the 4 species of sea urchin graphically (Fig. 6). Not a single pair of species of sea urchin has a complete overlap. The greatest overall similarity is shown by Pseudechinus magellanicus and Austrocidaris canaliculata. However, both species have a significantly different utilization of holdfast of $M$. pyrifera.

\section{DISCUSSION AND CONCLUSIONS}

Little is known of the factors regulating the pattern of distribution and the abundance of the several species of sea urchins occurring in the forest of $\mathrm{Ma}$ crocystis pyrifera from southern South America. Previous studies (Mortensen, 1952; Pawson, 1965, 1966; Barrales and Lobban, 1975) have only reported on the taxonomic identity of these species, sometimes characterizing the type of habitat where they occur in a rather general way. Our results show that the 4 species of sea urchins studied change their range of bathymetric distribution from areas with low water movement to those with high movement. With the exception of Arbacia dufresnei all other species show a more restricted bathymetric distribution in sheltered areas. Further, all species of sea urchins, but Austrocidaris canaliculata, increased their densities in exposed areas.

The results of measurements of microhabitat used by these species of sea urchins indicate that with the exception of Pseudechinus magellanicus and Austrocidaris canaliculata there is low overlap in microhabitat used by them. $P$, magellanicus and $A$. canaliculata share a diversity of rather cryptic microhabitats such as crevices, under boulders and holdfast of Macrocystis pyrifera. Nevertheless, even though they have a high overlap, they show some segregation, thus $A$. canaliculata was more frequently found in crevices and under boulders while $P$. magellanicus occurred mostly in holdfast of $M$. pyrifera.

The results on gut contents indicate that the 4 species include fronds of Macrocystis pyrifera in their diets, showing a high degree of overlap among several pairs of species. Nevertheless, 3 species: Loxechinus albus, Arbacia dufresnei and Austrocidaris canaliculata consumed other species of algae (frondose 

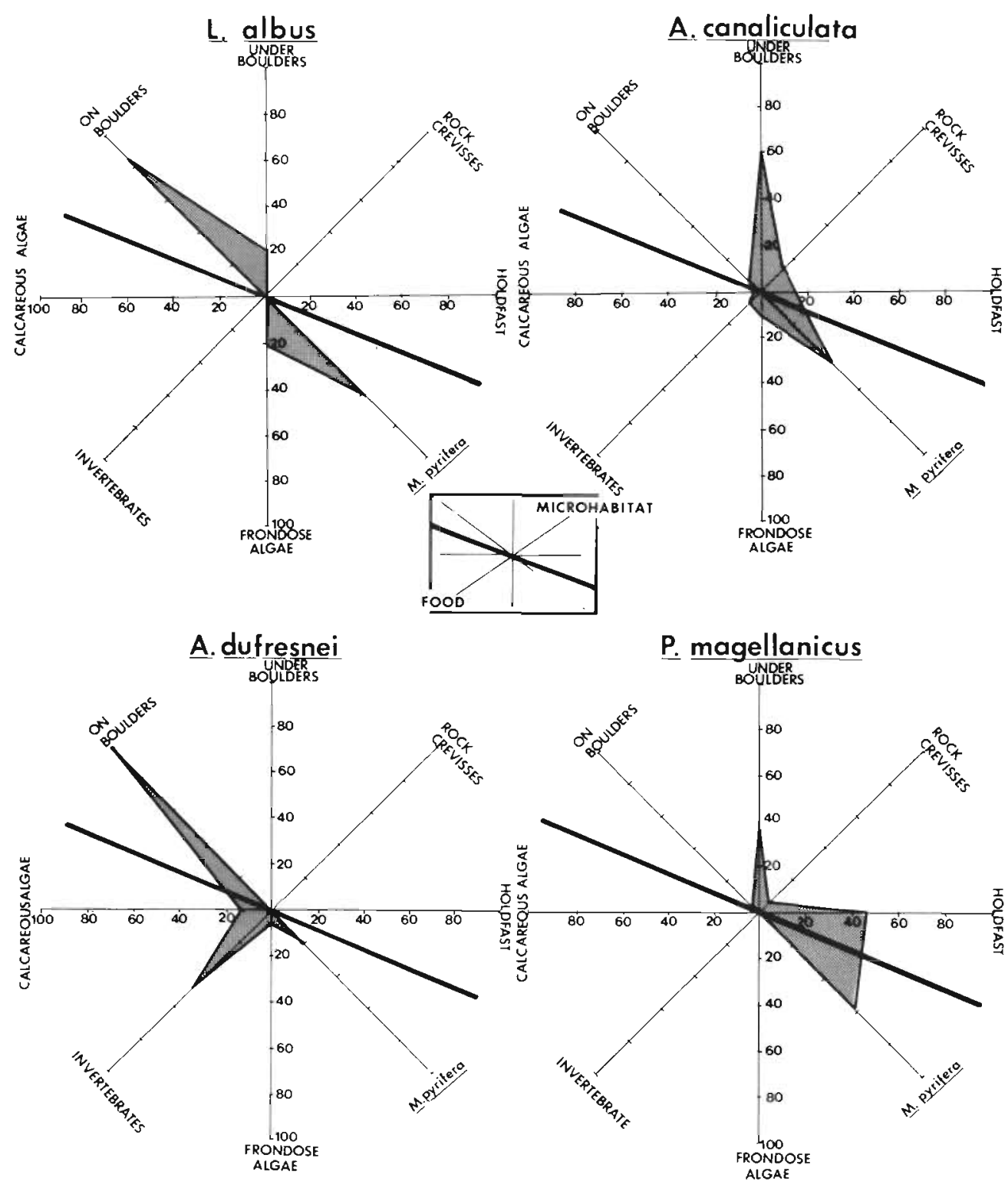

Fig. 6. Utilization of food and microhabitat resources by 4 sea urchins species in the forest of Macrocystis pyrifera from Puerto Toro, southern Chile. Values in axes correspond to percentage of utilization by each species

and calcareous) and one of them, A. dufresnei, consumed mainly invertebrates (serpulid polychaetes, barnacles, sponges). Furthermore, according to a related experimental study performed in this Macrocystis bed, the fronds of $M$. pyrifera, the main food item in 3 of the sea urchin species, do not appear as a limiting resource. Indeed, Castilla and Moreno (1982) showed $L$. albus, one of the most conspicuous species of sea urchin in the belt, to be consuming mainly pieces of drifting fronds and having no significant effect on recruitment or survival of juvenile $M$. pyrifera. In addition, Santelices and Ojeda (1984) showed that the pattern of recruitment of $M$. pyrifera is deter- mined mainly by the presence of adult canopy rather than by grazers.

Even though experimental manipulation of these species is still needed in the beds of Macrocystis pyrifera of Puerto Toro to rule out definitively the importance of intraspecific competition as maintaining the present pattern of distribution, the available data suggest little overlap of these 4 species in microhabitat and high overlap food, a resource which does not seem to be limiting.

Acknowledgements. This report is part of a comprehensive study on the biology and utilization of Macrocystis pyrifera in 
Table 3. Number of intercepted points (No.) and relative abundance $\left(\mathrm{R}_{\mathrm{a}} \%\right)$ of the various food items found in the gut contents of the 55 individuals of the 4 sea urchins collected at the 2 study sites in the forest of Macrocystis pyrifera at Puerto Toro, southern Chile

\begin{tabular}{|c|c|c|c|c|c|c|c|c|}
\hline \multirow[t]{2}{*}{ Food items } & \multicolumn{2}{|c|}{ L. albus } & \multicolumn{2}{|c|}{ P. magellanicus } & \multicolumn{2}{|c|}{ A. canalicuta } & \multicolumn{2}{|c|}{ A. dufresnei } \\
\hline & No & $\mathrm{R}_{\mathrm{a}} \%$ & No. & $\mathrm{R}_{\mathrm{a}} \%$ & No. & $\mathrm{R}_{\mathrm{a}} \%$ & No. & $\mathrm{R}_{\mathrm{a}} \%$ \\
\hline M. pyrifera & $(749)$ & 64.0 & (931) & 60.8 & $(450)$ & 45.5 & $(245)$ & 19.4 \\
\hline E. falklandica & (59) & 5.0 & & & & & (11) & 0.87 \\
\hline L. flavicans & $(137)$ & 11.7 & & & & & & \\
\hline L. vadosa & (14) & 1.2 & & & & & & \\
\hline G. skottsbergii & (33) & 2.8 & & & & & $(36)$ & 2.86 \\
\hline C. variegata & (9) & 0.8 & & & & & & \\
\hline H. hordacea & & & & & & & (11) & 0.87 \\
\hline P. secundatum & & & & & $(90)$ & 9.1 & & \\
\hline \multicolumn{9}{|l|}{ Codium sp. } \\
\hline Lithothamnion sp. & & & & & $(35)$ & 3.5 & $(152)$ & 12.0 \\
\hline Serpulids & & & & & (17) & 1.7 & $(278)$ & 22.0 \\
\hline Barnacles & & & & & $(38)$ & 3.8 & (351) & 27.86 \\
\hline Sponges & & & & & (21) & 2.1 & & \\
\hline Unidentified & (169) & 14.4 & $(247)$ & 16.1 & (69) & 7.0 & (71) & 5.6 \\
\hline No contents & & & $(352)$ & 23.0 & $(270)$ & 27.3 & $(105)$ & 8.3 \\
\hline Total & 1,170 & $100 \%$ & 1,530 & $100 \%$ & 990 & $100 \%$ & 1,260 & $100 \%$ \\
\hline
\end{tabular}

southern Chile. The work was financed through a research grant agreed on between the Armada de Chile and the Pontificia Universitad Católica de Chile. We thank R. Bravo, G. Casanova, H. Castillo, A. Jullian, A. Larrea, C. Moreno and F. P. Ojeda for much help in the fieid, and $J$. Pearse for critically reading the manuscript. We acknowledge the suggestions made by 3 referees.

\section{LITERATURE CITED}

Barrales, H. L., Lobban, C. S. (1975). The comparative ecology of Macrocystis pyrifera with emphasis on the forest of Chubut, Argentina. J. Ecol. 63: 657-677

Breen, P. A., Mann, K. H. (1976a). Changing lobster abundance and the destruction of kelp beds by sea urchins. Mar. Biol. 34: 137-142

Breen, P. A., Mann, K. H. (1976b). Destructive grazing of kelp by sea urchins in Eastern Canada. J. Fish. Res. Bd Can. 33: $1278-1283$

Castilla, J. C., Moreno, C. (1982). Sea urchins and Macrocystis pyrifera: experimental test of their ecological relations in southern Chile. In: Lawrence, J. M. (ed.) International echinoderm conference, Tampa Bay. A. A. Balkema, Rotterdam, p. 257-263

Chapman, A. R. O. (1981). Stability of sea urchins dominated barren grounds following destructive grazing of kelp in St. Margaret's Bay, Eastem Canada. Mar. Biol. 62: 307-311

Doty, M. S. (1971). Measurement of water movement in reference to benthic algal growth. Botanica mar. 14: 32-35

Druehl, L. D. (1978). The distribution of Macrocystis integrifolia in British Columbia as related to environmental parameters. Can. J. Bot. 56: 69-79

Duggins, D. O. (1980). Kelp beds and sea otters: an experimental approach. Ecology 61: 447-453

Estes, J. A., Palmisano, J. F. (1974). Sea otter: their role in structuring nearshore communities. Science, N.Y. 185: 1058-1060

Estes, J. A., Smith, N. S., Palmisano, J. F. (1978). Sea otter predation and community organization in the western Aleutian Island, Alaska. Ecology 59: 822-833

Foreman, R. E. (1977). Benthic community modifications and recovery following intensive grazing by Strongylocentrotus droebachiensis. Helgoländer wiss. Meeresunters. 30: $468-484$

Jones, S. J., Kain, J. M. (1967). Subtidal algal colonization following the removal of Echinus. Helgoländer wiss. Meeresunters. 15: 460-466

Lawrence, J. M. (1975). On the relationships between marine plants and sea urchins. Oceanogr. mar. Biol. A. Rev. 13 213-286

Leighton, D. L., Jones, L. G., North, W. J. (1965). Ecological relationships between giant kelp and sea urchins in southern California. Vth International Seaweed Symposium 5: $145-153$

Lowry, L. F., Pearse, J. S. (1973). Abalones and sea urchins in an area inhabited by sea otters. Mar. Biol. 23: 213-219

Mattison, J. E., Trent, J. D., Shanks, A. L., Akin, T. B., Pearse, J. S. (1977). Movement and feeding activity of Red Sea urchins (Strongylocentrotus franciscanus) adjacent to a kelp forest. Mar. Bíol. 39: 25-30

Mortensen, Th. (1952). Reports of the Lund Chile Expedition 1948-1949. Echinoidea and Ophiuroidea. Acta Univ. Lund N.F. 2: $1-22$

Muus, B. J. (1968). A field method for measuring exposure by means of plaster balls. A preliminary account. Sarsia 34: $61-68$

North, W. J., Pearse, J. S. (1970). Sea urchin population explosion in southern California coastal waters. Science, N.Y. $167: 209$

Pawson, D. L. (1965). Echinoderm studies in southern Chile. Antarctic J., U.S. 5: 192

Pawson, D. L. (1966). The echinoidea collected by the Royal 
Society of London expedition to southern Chile, 1958-1959. Pacif. Sci. 20: 206-211

Pearse, J. S., Hines, A. H. (1979). Expansion of a central California kelp forest following the mass mortality of sea urchins. Mar. Biol. 51: 83-91

Santelices, B., Ojeda, F. P. (1984). Population dynamics of coastal forests of Macrocystis pyrifera in Puerto Toro, Navarino Island, southern Chile. Mar. Ecol. Prog. Ser. 14: 175-183
Vadas, R. L. (1977). Preferential feeding. An optimization strategy in sea urchins. Ecol. Monogr. 47: 337-371

Vance, R. R. (1979). Effects of grazing by the sea urchin Centrostephanus coronatus on prey community composition. Ecology 60: 537-546

Vance, R. R., Schmitt, R. J. (1979). The effect of the predator avoidance of the sea urchin Centrostephanus coronatus on the breadth of its diet. Oecologia (Berl.) 44: 21-25

This paper was presented by Professor J. S. Pearse; it was accepted for printing on May 7, 1984 